\title{
DIVORŢUL DUPĂ LEGISLAŢIA CIVILĂ DIN SECOLUL AL IV-LEA ŞI CANOANELE SFÂNTULUI VASILE CEL MARE
}

Constantin Rus*

Abstract: In this study we try to speak about the divorce both according to civil legislation of the fourth century and according to the holy canons of St. Basil the Great. This study is devided into two parts. The first part deals with the divorce and adultery according to the civil legislation of the fourth century. The second part deals with the same issues according to the canons of St. Basil the Great.

Keywords: adultery, divorce, canon law, roman law, byzantine law, civil law, canons of St. Basil the Great, repudium.

\section{Introducere}

Cunoaşterea precisă, chiar detaliată, a legislaţiei romane despre divorţ şi adulter este esenţială pentru a înţelege domeniul de aplicare a hotărârilor Bisericii şi a gândirii Sfinţilor Părinţi, din secolul al IV-lea, despre această temă. Dar mai mult decât orice altceva, ea se impune celui care vrea să cunoască doctrina şi conduita Sfântului Vasile cel Mare. Este necesar să dăm, la începutul acestui studiu, o privire de ansamblu asupra acestei probleme după dreptul roman: acesta este obiectul primei părţi. Partea a doua va dezvolta ansamblul prescripţiilor canonice ale Sfântului Vasile cel Mare privind separarea soţilor, cauzele care au autorizat-o, sancţiunile suportate, dar în scopul foarte precis de a şti dacă el recunoaşte soţilor divorţaţi, cel puţin în unele cazuri, dreptul de a contracta o nouă căsătorie valabilă şi aprobată de către Biserică. Aş dori, într-un cuvânt, să precizez natura adevărată a divorţului care acceptă separarea simplă sau separarea totală cum solutione vinculi.

* PhD Rev Professor, Faculty of Orthodox Teology „Ilarion Felea”, „Aurel Vlaicu" University, Arad, Romania. 
Importanţa acestui studiu nu a scăpat nimănui; ea a interesat exegetul, teologul, canonistul. Cei care au parcurs, chiar mai repede, scrisorile canonice ale Sfântului Vasile cel Mare au observat complexitatea problemelor pe care le reprezintă cu privire la divorţ. Ele sunt cu atât mai grave cu cât aceste scrisori reproduc practica unei Biserici, aceea din Capadocia. De altfel, ele au fost admise mai târziu la numărul izvoarelor oficiale ale dreptului bisericesc din Răsărit. Prin ele canoniştii ortodocşi au justificat mult timp practica Bisericilor lor, care a făcut din divorţ un obicei atât de extins. Canoniştii Catolici înşişi au fost împărţiţii la rândul lor şi încă în zilele noastre nu există niciun acord între ei. Mi se pare, totuşi, că acest acord este posibil în jurul interpretării pe care eu aş numi-o canonică, fondată chiar pe scopul scrierii în cauză şi nu priveşte eliminarea sau absenţa pedepsei ca pe o aprobare, ci o vede ca pe o indulgenţă simplă de ordin practic.

Această interpretare este veche şi cunoscută. La început, Palmieri ${ }^{1}$ a semnalat-o în tratatul său excelent despre căsătorie, iar apoi şi alţi cercetători contemporani ${ }^{2}$. Dar, dacă ea este incontestabilă în principiu, punerea sa în aplicare este complexă şi, uneori, se ciocneşte de dificultăţi astfel încât au făcut să o abandoneze o serie de autori. Cei care o admit, de altfel, uneori slăbesc forța sprijininduse pe traducerile incerte sau nu o pun suficient în valoare, sau greşesc să facă din ea centrul întregii lor explicaţii. Prin urmare, nu va fi inutil să reluăm, pe această bază, studiul acestor canoane şi să o dezvoltăm cu toată amploarea. Numai astfel, vom încerca să o dovedim, pentru a ne da seama de rigurozitatea textelor, fără a pune

${ }_{1}^{1}$ Palmieri, De matrimonio christiano, Rome, 1896, p. 159 şi 169.

2 Dintre cercetătorii moderni, care au tratat această problemă, amintim: Joseph Prader, Il Matrimonio in Oriente e in Occidente, Rome, Italy, Pontificio Istituto Orientale, 2003, în special, pp. 291-294; E Molcuţ, Drept privat roman, Bucureşti, Universul Juridic, 2011; Mihai Vasile Jacotă, Drept privat roman, Iaşi, Chemarea, 1998; Teodor Sâmbrian, Institutiile de drept roman, Sitech, Craiova, 2009; A. Di Pietro, „El divorcio en el derecho romano”, în Anuario Argentino de Derecho Canonico, 3 (1996), pp. 169-210; A. Di Pietro, „El Derecho Romano Cristiano", în Anuario Argentino de Derecho Canonico, 9 (2002), pp. 117-140. 
pe Sfântul Vasile cel Mare în contrazicere nici cu el însuşi, nici cu Sfinţii Părinţi din epoca lui. Nu ne vom lăuda că vom risipi tot întunericul pe care îl proiectează asupra operei atât de clare a Arhiepiscopului Cezareei unele dintre canoanele sale. Am dori, cel puţin, să o circumscriem cu metoda şi s-o readucem la adevăratele sale proporţii.

\section{Divorţul după legislaţia civilă}

Autorii care doresc să cunoască legislaţia civilă privind divorţul din epoca Sfinţilor Părinţi, de obicei se mulţumesc să vorbească de Constantin cel Mare şi citează legea sa din anul 331. Într-adevăr, ea este foarte importantă, dar nu este singura lege care a existat atunci; de asemenea, nu este chiar ea aceea care a avut cea mai mare influenţă asupra moralei creştine. Dacă dorim să ţinem seama de situaţia de fapt de mai înainte în care se găsea Biserica atunci când a început să intervină în acest domeniu, trebuie să ne întoarcem până la împăratul Augustus şi la celebre legi Juliene (leges Juliae).

G. Boissier ${ }^{3}$ a prezentat foarte fin prin ce combinaţii de circumstanţe împăratul Augustus a fost nevoit să legifereze despre căsătorie. La sfârşitul Republicii, autorizaţia, la Roma, era extremă şi slăbirea moralei a devenit un adevărat flagel public. Preocupat de pericolele care au prevestit în fiecare zi imperiului o depopulare în creştere şi grijuliu să menajeze Italia ca şi celelalte provincii de arme atât pentru a lucra cât şi pentru a lupta, el a hotătât, încă de când a venit la putere, să ofere o cale de atac împotriva acestui fapt. El a încercat în primul rând să influenţeze opinia publică prin mijloace necinstite: poeţii, istoricii, oratorii s-au transformat dintr-o dată, ca un slogan, în predicatori ai moralităţii, ,dar ne-am dat seama curând că îndemnurile poeţilor nu erau suficiente pentru a da acestor efeminaţi gustul să doarmă pe ceva dur sau să conducă plugul. A trebuit să folosească metode mai eficiente şi s-a încercat să forţeze pe

3 G. Boissier, La Religion romaine d'Auguste aux Antonius, t. I-er, Paris, Librairie Hachette et Cie, 1874, pp. 82-85. 
cei care nu au putut convinge". Senatul şi partea rămasă sănătoasă opiniei publice l-au presat pe Augustus să-i pedepsească sever. Cu toate acestea el a ezitat. El a refuzat, în anul 732, cenzura publică, care i-a dat puterea de a dezaproba, dar el a acceptat, trei ani mai târziu, direcţia legilor şi a obiceiurilor (morum et legum regimen), care i-au investit o putere mult mai mare, acea „de a pedepsi şi de a sprijini noile reglementări”. Prin aceasta, împăratul s-a declarat gata să meargă mai departe. De fapt, în anul 736, probabil cu optsprezece ani înainte de Iisus Hristos, cea mai importantă dintre legile iuliene despre căsătorie a fost promulgată, adică Lex Julia de adulteriis et pudicitia.

G. Boissier ${ }^{4}$ a spus, nu fără răutate, după Dio Cassius, cum Augustus a fost nevoit, împotriva lui însuşi, să transforme în legi de stat sfaturile intime pe care el însuşi le dădea impărătesei Livia. Acest cod de morală fusese oarecum pregătit de legile Lex Papia Poppoea, Lex Julia de maritandis ordinibus şi a fost urmat de altele la fel de importante, Lex Julia de undo dotali, de tutela, etc.

Nu putem să dăm aici, oricât de interesante ar putea părea, în special astăzi, detalii cu privire la administrarea savantă unde totul este calculat pentru a încuraja pe părinţii familiei şi de a le acorda beneficii proporţionale cu numărul de copii, în timp ce familia necăsătorită şi sterilă va deveni treptat victimă a fiscului ${ }^{5}$. Dar trebuie să ne oprim asupra măsurilor luate pentru combaterea adulterului şi reducerea divorţurilor. Aceste două subiecte depind unul de celălalt şi se completează reciproc. Vom găsi atât în unul cât şi în celălalt nenumărate informaţii utile pentru înţelegerea legislaţiei bisericeşti.

Cele mai multe dintre măsurile luate împotriva adulterul au rămas în Lex Julia de adulteriis coercendis din Digeste 6 . Pentru cititorul care se va teme de o plimbare puţin aridă în Corpus Juris

${ }^{4}$ G. Boissier, La Religion romaine d'Auguste aux Antonius, t. I, pp. 83-84.

${ }^{5}$ F. De Champagny ne oferă câteva dispoziţii în lucrarea sa, Les Césars, Paris, 1876, pp. 248-252.

${ }^{6}$ Digeste, XLVIII, 5. 
Civilis, vom da un scurt rezumat, în urma analizei excelente a lui G. Humbert, din Dictionnaire des Antiquités greques et romaines ${ }^{7}$.

Să reţinem în primul rând definiţia, care este fundamentală. Adulterul, adulterium, este, după această lege, „,comportamentul femeii măritate de a trăi cu un alt bărbat decât soţul ei”. Prin urmare, este adulteră, adultera, orice femeie măritată care comite această crimă şi complicele său, căsătorit sau nu, este adulter. Acest din urmă termen nu desemnează, în sine, soţul infidel vis-a-vis de soţia lui (această infidelitate nu a fost condamnată de lege, iar femeia nu avea niciun drept de a controla comportamentul soţului său), ci omul care a provocat necazuri unui soţ prin legături nepermise cu soţia sa. Din aceasta a rezultat că soţul nu a fost afectat de aceste legi, dacă avea relaţii cu o persoană necăsătorită; nu a existat nicio ,încălcare legală a credinţei conjugale". Augustus a menţinut această noţiune tradiţională. $\mathrm{Cu}$ toate acestea, el a luat o măsură pozitivă, tratând ca adulter orice complice care a cooperat la crimă prin sfat, ajutor sau adăpost date pentru a realiza acest delict.

El răstrânge dreptul vechi de răzbunare personală, dar nu-1 poate suprima. Soţul şi tatăl aveau dreptul să sacrifice imediat pe cei doi vinovaţi dacă i-ar fi surprins în flagrant. Cato cel Bătrân se laudă în această propoziţie cu o energie cumplită: in adulterio uxorem tuam si deprehendisses, sine judicio impune necares şi adaugă cu o mândrie naivă: illa te, si tu adulterarere, digito non auderet contingere, neque jus est. După noua lege, tatăl îşi va păstra dreptul său în anumite condiţii: el trebuia să-şi păzească autoritatea părintească pe care o avea asupra fiicei sale atunci când îi prindea pe vinovaţ̧i în flagrant delict în casa lui sau a soţului şi în cele din urmă el îi ucidea pe cei doi împreună. Era omucidere dacă una din aceste condiţii lipsea. Cât priveşte pe soţ, el nu putea să-şi ucidă soţia nici complicele (în afară de cazul când acesta era de condiţie inferioară); dar trebuia, dimpotrivă, să-şi izgonească femeia şi, sub ameninţarea de a continua el însuşi ca mijlocitor al corupţiei, s-o denunţe în trei

7 Daremberg-Saglio, „Adultére”, în Dictionnaire des Antiquités greques et romaines, t. I-er, Paris, Librairie Hachette et Cie, 1874, pp. 85-87. 
zile autorităţii. Răzbunarea personală va fi înlocuită din ce în ce mai mult prin acţiunea publică.

Dreptul de acuzare a rămas rezervat, timp de şaizeci de zile, soţului şi tatălui femeii, dar, trecând această dată, în următoarele patru luni, orice om putea deveni acuzator şi să denunţe, împreună sau succesiv, pe adulteră şi pe complicele ei. Plângerea trebuia să fie scrisă (inscriptio libelli accusatorii) în funcţie de anumite forme legale necesare sub sancţiunea pierderii procesului (inscriptio in crimen). În cele din urmă, era necesar ca acţiunea să fie introdusă în termen de şase luni pentru femeie şi în cinci ani pentru complicele ei.

Pedeapsa legală a adulterului a fost relativ benignă, în comparaţie cu cea a vechilor romani. Femeia era condamnată la exil pe o insulă, sau, poate, în timpul lui Augustus, la acest fel de exil de un anumit tip care a fost interdictio aquae et ignis; ea abandona în casa soţului ei jumătate din zestrea ei şi o treime din bunurile sale; ea nu mai putea contracta o căsătorie „legală”, adică legitimă, dar totuşi îi era permis concubinatus; în cele din urmă, ea nu mai avea dreptul de a purta stola matroanelor, ci trebuia să îmbrace toga curtezanelor.

Adulterul era exilat într-o insulă diferită de cea a complicele lui confiscându-i-se jumătate din averea sa; unele sechestrate civile, incapacitatea de a fi martor, soldat, etc., completau pedeapsa sa.

Aceste prescripţii referitoare la adulter nu au suferit decât modificări de mică importanţă până în secolul al IV-lea.

Constantin cel Mare, sub influenţa ideilor creştine, mai mult decât din necesitate politică, a modificat în mai multe puncte aceste prescripţii privind adulterul, în sensul unei mai mari rigori, cel puţin cât priveşte pedeapsa. Adulterul era condamnat la moarte prin sabie şi la confiscarea averii. În ceea ce priveşte pe femeia vinovată, ea nu era pedepsită cu moartea decât în cazul în care complicele ei era propriul ei sclav; în afară de acest caz, exilul rămânea pedeapsa sa principală. $\mathrm{Cu}$ toate acestea, în scopul foarte lăudabil de a evita acuzaţiile false, ne volentibus temere liceat foedare connubia, printro constituţie din anul $326^{9}$. Constantin cel Mare şi-a rezervat dreptul

${ }_{9}^{8}$ Codex Justinianus, IX, 9: Ad legem Juliam de adulteriis et stupro.

${ }^{9}$ Codex Justinianus, IX, 9, 29. 
de a da în judecată doar rudele, pe tată, pe frate, pe unchi (din partea tatălui şi a mamei), în afară de soţ, care putea să se prezinte ca acuzator chiar la o simplă suspiciune.

Fiii lui Constantin cel Mare, Constant şi Constanţiu, printr-o constituţie din 29 august $329^{10}$, chiar au agravat pedeapsa pentru adulter, asimilând-o cu paricidele pe care le impunea sulpiciu, culeus: criminalul era aruncat în mare după ce era cusut într-un sac de piele cu un câine, o maimuţă, un cocoş şi o viperă. Renunţ să dau sensul mistic al acestui ritual.

Dar pentru a restabili familia şi a-i reda fecunditatea, nu era suficient de a ataca adulterul. A trebuit să-i dea mai multă stabilitate şi să pună o frână abuzurilor de divorţ. Augustus, de asemenea, s-a folosit de aceasta. Până la sfârşitul Republicii, toate căsătoriile puteau fi dizolvate, cele care au fost legitime (justae nuptiae) sau nelegitime (injusta matrimonia). Din cele trei feluri de căsătorii „legale" (confarreatio, coemptio, usus), numai prima, confarreatio, a fost indisolubilă, se crede, cel puţin dintr-un anumit motiv, probabil din cauza ceremoniei religioase care o însoţea şi îi dădea un caracter sacru. Mai devreme, cu toate acestea, au fost admise excepţii şi consacrate chiar de legea celor Douăsprezece Table. De altfel, confarreatio s-a pierdut rapid şi, odată cu ea, principiul indisolubilităţii legăturii conjugale: ea nu a mai fost reţinută decât pentru preotul lui Jupiter, până în timpul lui Diocleţian. În afară de acest caz, înainte de epoca lui Augustus, orice căsătorie legitimă putea fi dizolvată. $\mathrm{Cu}$ atât mai mult căsătoriile nelegitime beneficiau de aceeaşi libertate. Contubernium (căsătoria sclavilor) era încă ignorată de lege: ea era dizolvată aşa cum era contractată, fără ca ea să se amestece. Cât priveşte concubinatus (căsătoria care nu are legătură legală încheiată între persoanele libere), a fost, de asemenea, mult timp scosă în afara legii, tolerată de către aceasta, dar privată de orice sancţiune oficială. Chiar şi atunci, cu Augustus, ea a dobândit un oarecare drept de cetăţenie şi aproape a devenit o uniune legală, deşi de ordine inferioară, ea nu a fost în mod evident mai stabilă decât justae nuptiae. Ele au fost, de fapt, una şi celălaltă, atât de des

${ }^{10}$ Digeste, XLVIII, 9, 9. 
dizolvate şi pentru astfel de motive Augustus şi-a rezervat dreptul şi datoria de a interveni.

Separarea se făcea în două moduri: prin consimţământul reciproc (divortium ex communi consensu sau de bona gratia); acesta a fost divortium propriu-zis sau discidium; - şi prin voinţa unuia dintre soţi notificată celuilalt de a desface căsătoria; acesta a fost repudium.

Cât priveşte divorţul prin consimţământul reciproc, împăratul nu îndrăznea sau nu dorea să aducă nici cea mai mică piedică. Romanii n-au văzut în căsătorie decât un contract şi n-au înţeles că ea nu putea fi reziliabilă decât în acelaşi mod ca orice contract, prin acordul celor două părţi. Constantin cel Mare se va abţine de la orice interdicţie împotriva acestei practici. Motta spune, este adevărat, contrariul $^{11}$, dar nu este clar pe ce text se bazează şi trebuie să recunoaştem că această apărare a trebuit să fie de curând ridicată, dar nu ştim când sau de cine. La începutul secolului al V-lea, vechiul obiceiul exista încă când Teodosie cel Tânăr ${ }^{12} 1$-a suprimat, de altfel pentru puţin timp.

Numai repudium, demiterea unuia dintre soţi de către celălalt, a fost obiectul primei reglementări de către legea Julia de adulteriis şi de către legea Julia şi Papia Poppaea. El nu a mai fost permis decât printr-o declaraţie verbală sau întocmirea unui înscris înaintea a şapte martori, având calitatea de cetăţeni romani, susţinută înaintea cenzorului, pe propria răspundere, că motivele pentru separare au fost reale.

În practică, a fost întotdeauna uşor pentru persoana în cauză, înainte de a merge la cenzor, de a se înţelege, împreună cu un grup de prieteni ${ }^{13}$, cu privire la motivele invocate, mai ales din moment ce nici un temei legal nu a fost stabilit în această privinţă. Celelalte condiţii impuse de către Augustus sunt incerte. Pomponius şi Ulpian vorbesc despre pedepsele prevăzute de lege împotriva acelui soţ din vina căruia divorţul a fost pronunţat, de exemplu, reţinerea zestrei

\footnotetext{
${ }^{11}$ De Jure div., p. 5.

${ }^{12}$ Codex Justinianus, V, 17, 8.

${ }^{13}$ Aulu-Gelle, I, XVII, c. XXI.
} 
femeii, etc. De fapt, aceste măsuri n-au pus nicio barieră de netrecut libertinajului, şi se pare că repudierile nu au scăzut foarte mult din cauza lor. Iniţial, deşi femeia a fost sub puterea soţului, in manu viri, el singur avea dreptul de a se folosi de ea; mai târziu, odată cu diminuarea lui manus, femeia putea să repudieze la fel ca soţul, atunci când ea era sui iuris, apoi, prin extindere, chiar şi cei care au fost in manu mariti în cele din urmă aveau sau li se îngăduiau să facă acest lucru ${ }^{14}$.

Eşecul încercării lui Augustus este semnalat de către toţi autorii. Ca şi înainte, mai mult decât oricând, s-a continuat să se divorţeze chiar şi pentru motivele cele mai triviale. Câte riduri de pe frunte, câte pete pe dinti, au fost de ajuns; dacă cineva îl crede pe Juvenal:

Tres rugae subeant et se cutis arida laxet,

Fiant obscuri dentes, oculique minores:

Collige sarcinulas, dicet libertus, et exi ${ }^{15}$.

Mai mult decât atât, simplul fapt de a se denunţa de foarte multe ori a servit ca un pretext:

Jam gravis es nobis et saepe emungeris; exi

Ocyus et properat. Sicco venit altera naso ${ }^{16}$.

Chiar şi această parte a satirei, reiese din aceste trăsături ale lui Juvenal că soţii s-au despărţit chiar şi fără un motiv serios. A fost necesar ca răul să fie atât de profund pentru ca Seneca să poată scrie această sentinţă severă: „Există încă o femeie care roşeşte de divorţ, atunci când vede ilustra şi nobila familie care numără anii lor, nu prin consuli, ci prin soţii care divorţează de căsătorie, care se căsătoresc pentru a divorţa? ${ }^{17}$ " Trebuie să ne mirăm de aceasta? Marelui

\footnotetext{
${ }^{14}$ Baudry, "Divorce", în Dictionnaire desAntiquités grecques et romaines, t. I, pp. 102-104.

15 Juvenal, Sat. VI, în Juvenal The Sixteen Satires, translated by Peter Green, London, Penguin Books, 1998, p. 81.

${ }^{16}$ Juvenal, Sat. VI, în Juvenal The Sixteen Satires, translated by Peter Green, London, Penguin Books, p. 81.

${ }^{17}$ Seneca, De Beneficiis., III, 16, edited by John W. Basore, Tufts University Press, 2015, p. 145.
} 
maestru al moralei în imperiu, Suetoniu, i s-au permis trei divorţuri ${ }^{18}$ şi se pot menţiona şi cele ale succesorilor săi.

Dar legiuitorul singur nu avea dreptate. Legea era inadecvată. Defect său cel mai grav a fost de a nu determina cu precizie cazurile în care divorţul a fost permis şi cele în care era pedepsit. Constantin cel Mare a înţeles aceasta şi a pus ordine în acest caz prin constituţia sa din anul 331. Dăm, aici, tot textul; el are o savoare aparte care nu se mai găseşte în Codurile moderne:

„Hotărâm că femeia nu poate să respingă, după voia instinctelor sale perverse, pe soţul ei pentru primul pretext, pentru că este, de exemplu, băutor, jucător sau desfrânat (muliercularius) iar soţii nu pot, în orice moment, să-şi destituie pe soţiile lor. Femeia nu va putea să dea repudium decât pentru următoarele infracţiuni ale soţului, adică dacă el este criminal, otrăvitor, violator de morminte; dacă ea făcea dovada despre aceasta, ea va beneficia de toată zestrea lui, dar pentru o altă cauză decât pentru una dintre aceste trei infracţiuni care 1-a repudiat, ea va trebui să lase în casa soţului până la ultimul ac al părului ei şi, drept răsplată pentru că a îndrăznit aceasta, să fie deportată pe o insulă. Cât priveşte pe soţii lor, ei nu vor putea să repudieze pe soţiile lor decât pentru una dintre cele trei infracţiuni; dacă ea este adulteră, otrăvitoare, mijlocitoare. În cazul în care unul dintre ei se întoarce nevinovat la aceste infracţiuni, el trebuia să-i restituie toată zestre sa şi nu să se recăsătorească; în cazul în care făcea aceasta, prima femeie va avea dreptul să invadeze casa sa şi să profite, pentru a răzbuna prejudiciul suferit, de toată zestrea rivalei sale" ${ }^{\prime \prime}$, inclusiv, fără îndoială, de acele de păr!

Acest text este fără ocolişuri. Aici, cel puţin, nu pare ca legiuitorul să aibă preocuparea de a-şi rezerva sieşi orice cale de ieşire, uneori de ajutor. Motivele legale pentru divorţ sunt reduse la cinci infracţiuni, aceea de otrăvire, valabilă pentru ambii soţi, cele de omucidere şi violator de morminte pentru soţ, cele de adulteră şi de mijlocitoare pentru femeie. Vom nota că infracţiunea de adulter nu este considerată decât din partea femeii. Ceea ce am spus mai sus explică destul de clar acest motiv. Chiar dacă soţul are relaţii ilicite

${ }^{18}$ Suetoniu, în Enciclopedia Britanică, accestată la 21 ianuarie 2016.

${ }^{19}$ Codex Theodosianus, III, 16, 1. 
cu o altă femeie măritată, el este adulter în raport cu bărbatul complicelui lui, dar nu faţă de nevasta lui, pentru care el nu va fi decât un muliercularius, un desfrânat, iar acest lucru pare să fie privit ca o greşeală mică care, în orice caz, nu permite separarea. După cum am văzut, legea lui Constantin cel Mare rămâne în tradiţia păgână. Creştinismul i-a inspirat mai multă severitate, dar n-a schimbat vechea concepţie despre natura infracţiunii.

\section{Divorţul după Epistolele canonice ale Sfântului Vasile cel Mare}

\section{1. Divorţul după Regulile Morale ale Sfântului Vasile cel Mare}

$\mathrm{Nu}$ se poate aborda cu succes studiul operei canonice a Sfântului Vasile cel Mare, fără a se cunoaşte activitatea sa morală: dreptul canonic este, în unele dimensiuni, dependent de moralitate. $\mathrm{Nu}$ ar fi fără pericol de a se dori să se extragă toată gândirea Sfântul Vasile cel Mare din documentele care, prin însăşi natura lor, prin destinaţia lor, prin numele lor, iau în considerare doar un aspect al adevărului, aspectul legal. Probabil doar prevederile canonice conţin, de asemenea, un element teologic pe care ele se bazează, dar nu-l pot obţine, prin generalizări care nu conţin texte înguste, speciale prin natura lor, concluzii care le depăşesc. Cel mai bun mod de a evita această capcană, în zona noastră de cercetare, este să se examineze mai întâi gândirea Sfântului Vasile cel Mare despre divorţ, în alte lucrări care ne-au rămas de la el. Această muncă va fi destul de confortabilă. De fapt, nu există decât un singur pasaj în care Arhiepiscopul Cezareei abordează ex professo această problemă, în Regulile Morale, dar el o face în aşa fel încât nu lasă nicio îndoială cu privire la conţinutul gândirii sale.

Această lucrare este, în esenţa sa, o colecţie de texte biblice, în primul rând din Sfintele Evanghelii sau Epistolele pauline. Acestea sunt grupate în capitole, precedate de un rezumat scurt. Capitolele sunt la rândul lor clasate în reguli, foarte inegale în lungime, în funcţie de domeniu; regula 70 cuprinde 27 de capitole, în timp ce multe alte nu au decât unul. Opera întreagă numără 80 de reguli. Prin urmare, toată lucrarea autorului constă în clasificarea pe 
probleme a textelor selectate şi mai ales în adăugarea la începutul capitolului a unei fraze mici, concisă şi completă, care rezumă sensul şi este de multe ori cel mai bun comentariu. Cazul celor două capitole ne interesează, primul şi al doilea ale regulei 73 , care se ocupă cu atribuţiile celor ce sunt căsătoriţi ${ }^{20}$.

Primul capitol poartă titlul: „Nu trebuie să se despartă bărbatul de femeie sau femeia de bărbat, decât numai pentru desfrânare sau dacă ar fi piedică spre pietate" ${ }^{21}$. Scopul capitolului este doar separarea soţilor. Textele ce-1 compun sunt: două versete celebre din Evanghelia după Matei despre divorţ:

„S-a zis iarăşi: Că oricine va lăsa pe femeia sa, să-i dea carte de despărţire. Eu însă vă spun vouă: Că oricine va lăsa pe femeia sa, în afară de pricină de desfrânare, o face să săvârşească adulter, şi cine va lua pe cea lăsată săvârşeşte adulter” (Matei 5, 31-32).

„Iar Eu zic vouă că oricine va lăsa pe femeia sa, în afară de pricină de desfrânare, şi se va însura cu alta, săvârşeşte adulter; şi cine s-a însurat cu cea lăsată săvârşeşte adulter" (Matei 19, 9).

Un scurt extras din Evanghelia după Luca referitor la renunţarea la familie cerută pentru ucenicii lui Hristos:

„Dacă vine cineva la Mine şi nu urăşte pe tatăl său şi pe mamă şi pe femeie şi pe copii şi pe fraţi şi pe surori, chiar şi sufletul său însuşi, nu poate să fie ucenicul Meu" (Luca 14, 26)

În sfârşit, două versete prin care Sfântul Apostol Pavel interzice soţilor să se despartă:

„Iar celor ce sunt căsătoriţi, le poruncesc, nu eu, ci Domnul: Femeia să nu se despartă de bărbat! Iar dacă s-a despărţit, să rămână nemăritată, sau să se împace cu bărbatul său; tot aşa, bărbatul să nuşi lase femeia" (I Corinteni 7, 10-11).

Scopul capitolului fiind separarea şi determinarea cauzelor care permit acest lucru, se explică prin faptul că Sfântul Vasile cel

${ }^{20}$ Sfântul Vasile cel Mare, Regulile Morale, în Părinţi şi Scriitori Bisericeşti, vol. 18: Sfântul Vasile cel Mare, Scrieri partea a II-a, Bucureşti, Editura Institutului Biblic şi de Misiune al Bisericii Ortodoxe Române, 1989. A se vedea şi Migne, P. G., XXXI, 849-850.

${ }^{21}$ Sfầntul Vasile cel Mare, Regulile Morale, în Părinţi şi Scriitori Bisericeşti, vol. 18: Sfântul Vasile cel Mare, Scrieri partea a II-a, regula 73, 1, p. 187. 
Mare nu citează pasajele unde Sfântul Marcu şi Sfântul Luca vorbesc despre divorţ, ci unde, preocupaţi în principal de a interzice căsătoria a doua, ei nu semnalează cazul unic în care Hristos permite separarea, adulterul; afirmaţia Sfântului Matei a fost de rigoare. Pentru un alt motiv de separare, pietatea, se referă cuvântul lui Iisus despre renunţare, dar, desigur, Sfântul Vasile cel Mare a avut, de asemenea, în vedere versetul 5 din capitolul VII din Epistola I către Corinteni: Să nu vă lipsiţi unul de altul decât cu bună invoială, pentru un timp, ca să vă îndeletniciţi cu postul şi cu rugăciunea. Este aceasta un plan care a fost omis, aşa cum este cunoscut suficient? Este aceasta o uitare? Sau că autorul, preocupat mai mult de a preciza natura separării permise şi de a preveni că ea nu autorizează în nici un fel o nouă căsătorie, citează pasajul unde Sfântul Apostol Pavel, în numele Hristos, o interzice în mod formal? Este greu de spus. Se pare că, ultimul verset (v. 11), ar fi cel mai bun plasament pentru capitolul următor. În plus, se poate anticipa, ea nu îşi pierde valoarea sa.

Capitolul al II-lea este dedicat exclusiv căsătoriei a doua a soţilor separaţi. În timp ce în capitolul anterior, s-a menţionat două cauze care permit separarea, aici se interzice o nouă căsătorie, fără nicio excepţie. El este următorul: „Nu este îngăduit celui care şi-a lăsat femeia lui să se căsătorească cu alta, nici celei lăsate de bărbat să se căsătorească cu altul"'22. Acestea sunt aceleaşi cuvinte ale titlului de la capitolul al II-lea. Ele servesc drept explicaţie a acestui verset al Sfầntului Matei, citat deja mai sus şi reprodus aici: „Iar Eu zic vouă că oricine va lăsa pe femeia sa, in afară de pricină de desfrânare, şi se va însura cu alta, săvârş̧eşte adulter; şi cine s-a însurat cu cea lăsată săvârşeşte adulter" (Matei 19, 9). Acest text a fost citat în capitolul I, care se ocupă cu separarea soţilor, din cauza primei părţi a versetului care o interzice, cu excepţia cazurilor de desfrânare, adică de adulter: aceste ultime cuvinte au aici valoarea lor. Acelaşi text este citat în partea a doua a capitolul al II-lea: „Oricine se căsătoreşte cu o altă femeie (după ce a fost lăsată)

${ }^{22}$ Sfântul Vasile cel Mare, Regulile Morale..., regula 73, 2, p. 187. 
săvârşeşte adulter; şi cel care se căsătoreşte cu o femeie lăsată săvârşeşte adulter".

Dar un punct rămâne obscur şi cere o explicaţie. Cuvintele $\hat{\imath}$. afară de pricină de desfrânare de la începutul versetului păstrează valoarea lor până la sfârşitul propoziţiei, aşa încât ar trebui să înţelegem astfel: oricine se căsătoreşte cu o altă femeie, după ce a fost lăsată este adulter cu excepția cazului în care a fost lăsată în caz de adulter; şi cine se căsătoreşte cu o femeie lăsată este adulter, în afară de cazul când a fost lăsată pentru adulter. Textul Sfântului Matei nu spune aceasta; ci presupune contrariul. Cu toate acestea, la rigoare, iar în cazul în care nimic altceva nu s-a opus, s-ar putea, cu puţină bunăvoinţă, să-1 determinăm să spună. Oricum, iată punctul care se luminează, acela despre care Sfântul Vasile cel Mare trebuie să-si concentreze explicaţia sa în rezumatul scurt pe care îl plasează în fruntea capitolului. Dacă cuvintele în afară de pricină de desfrânare îşi păstrează valoarea pentru el, el trebuie să le scoată în evidenţă. Dar ce face? El le elimină complet din propoziţia sa: nu este îngăduit celui care şi-a lăsat femeia lui să se căsătorească cu alta, nici celei lăsate de bărbat să se căsătorească cu altul. Singura diferenţă semnificativă care există între explicaţie şi text este de a explica eliminarea cuvintelor suspecte ${ }^{23}$. Ce e mai elocvent să spunem că nu au nicio valoare aici? Şi nu se poate presupune că ele sunt subînţelese. În primul rând, bunul simţ nu poate accepta că un autor, în explicaţia unei propoziţii obscure, a subînţeles exact cuvintele cele mai importante, mai ales când le-a pus în valoare, atunci când sensul era evident şi nu a necesitat nicio lămurire, în primul capitol. Dar, din nou, în cazul în care cuvintele sunt subînţelese, al doilea capitol şi-a pierdut raţiunea de a fí şi ceea ce se spune a revenit în cadrul primului capitol, mai ales că textul citat în al doilea caz este reprodus din primul. Împărţirea în capitole separate nu poate fi explicată decât dacă cazurile sunt rezolvate într-un mod diferit: separarea soţilor este permisă în ambele cazuri; noua lor căsătorie este interzisă fără nicio excepție. Exegeza Sfântului Vasile

${ }^{23}$ Ibidem. 
cel Mare este perfectă iar doctrina sa foarte fermă şi precisă; căsătoria nu este permisă bărbatului divorţat de soţia care trăieşte.

\section{2. Divorţul după Epistolele canonice ale Sfântului Vasile cel Mare}

Dintre numeroasele scrisori rămase de la Sfântul Vasile cel Mare către Amfilohie, episcop de Iconium, trei au primit, din antichitate, titlul de canonice. Acestea sunt: epistola $188^{24}$, din anul 374 , prima epistolă canonică; epistola $199^{25}$, din anul 375 , a doua epistolă canonică; şi epistola $217^{26}$, din anul 375 , a treia epistolă canonică. Pentru canonişti, cele trei epistole canonice formează un tot, împărţit în 85 de canoane (16 în prima epistolă, 34 în a doua, iar 35 în a treia). Vom urma această metodă şi ne vom mulţumi să menţionăm numărul canonului (după colecţia Părinţi şi Scriitori Bisericeşti $)^{27}$ fără să desemnăm Epistola. Un număr foarte mare din aceste canoane se referă la căsătorie şi cele mai multe tratează direct divorţul, din punctul de vedere de care ne ocupăm. Acestea sunt mai ales canoanele 9, 21, 22, 35, 46, 48, 58, 59 şi 77. Multe sunt clare prin ele însele; altele au nevoie de o explicaţie. Trebuie să le cităm pe toate pentru a ne face o idee exactă despre doctrina canonică a Sfântului Vasile cel Mare. Cu toate acestea, ordinea istorică nu este obligatorie. Aceasta nu va denatura sensul de a începe cu cele mai clare, pentru a face să beneficieze alţii de informaţiile pe care ele ni le furnizează. Cel mai important dintre toate şi cel mai vechi, canonul

24 Sfầntul Vasile cel Mare, Scrisori, Epistola 188 către Amfilohiu despre canoane, traducere, studiu introductiv, comentarii şi note de Pr. Prof. Teodor Bodogae, în Părinţi şi Scriitori Bisericeşti, vol. 12: Sfântul Vasile cel Mare. Scrieri, Partea a III-a, Despre Sfântul Duh. Corespondenţă (Epistole), Bucureşti, Editura Institutului Biblic şi de Misiune al Bisericii Ortodoxe Române, 1988, pp. 373-382. A se vedea şi Migne, P. G., 32, 663 şi urm.

25 Sfầntul Vasile cel Mare, Scrisori, Epistola 199 către Amfilohiu despre canoane, în Părinţi şi Scriitori Bisericeşti, vol. 12, pp. 400-409. A se vedea şi Migne, P. G., 32, 715 şi urm.

${ }^{26}$ Ibidem, pp. 443-450. A se vedea şi Migne, P. G., 32, 794 şi urm.

${ }^{27}$ A se vedea şi colecţia lui I. B. Pitra, Juris ecclesiasticii graecorum historia et monumenta jussu Pii IX, t. I, 1864, pp. 576-601 (în continuare, vom cita: Juris). 
9 , este şi cel care oferă cele mai multe dificultăţi. Nu-l vom aborda decât după ce vom studia, în introducere, distribuirea pedepselor, după canoanele 21, 22, 58, 59 şi 77.

În Răsărit, în secolul al IV-lea, penitenţa canonică cuprindea patru grade pe care penitentul trebuia să le treacă înainte de a fi iertat şi admis la comuniune. Aceste grade sunt: 1) plângătorii sau tânguitorii (prosklaiontes) care trebuiau să petreacă afară, la uşa Bisericii, unde-şi plângeau păcatele şi rugau pe cei care intrau în Biserică să se roage pentru ei, 2) ascultătorii (akroomenoi) care stăteau în pronaos, şi aveau voie să asculte Sfânta Liturghie până la citirea Apostolului şi a Evangheliei; 3) ingenunchetorii (gonyklinontes) sau cei ce se prosternează (ypopiptontes) care aveau voie să facă mătănii împreună cu cei credincioşi şi să asculte Sfânta Liturghie până la Liturghia credincioşilor; 4) cei care stau în picioare (synestontes) şi care puteau petrece în biserică pe toată durata Sfintei Liturghii, dar nu puteau participa la Sfintele Taine. Abia după aceea erau primiţi din nou între creştini. Nu este loc să insistăm în detaliu cu privire la timpul petrecut în fiecare categorie. Ceea ce ne interesează este durata totală a pedepsei.

Canonul $58^{28}$ fixează la cincisprezece ani pedeapsa pentru adulter. Canonul 5929, care-i corespunde, impune şapte pentru desfrânat, în timp ce canonul $22^{30}$ doar patru ani pentru aceeaşi infracţiune. Ne întrebăm de ce aceste diferenţe în pedepse, patru ani şi şapte ani pentru aceeaşi desfrânare. Explicaţia general acceptată din timpul lui Aristen, şi care pare certă, este că Sfầntul Vasile cel Mare recunoaşte două tipuri de desfrânare: una, simplă, este păcatul comis de către persoanele necăsătorite; alta, gravă, este păcatul

28 Sfântul Vasile cel Mare, Scrisori, Epistola 217 către Amfilohiu despre canoane... p. 446: „Cel ce a săvârşit adulter va fi exclus vreme de 15 ani de la Sfintele Taine",; a se vedea şi I. B. Pitra, Juris., t. I, p. 596.

29 Sfântul Vasile cel Mare, Scrisori, Epistola 217 către Amfilohiu despre canoane..., p. 446: „Desfrânatul va fi lipsit vreme de 7 ani de împărtăşania celor sfinte",; a se vedea şi I. B. Pitra, Juris, t. I, p. 596.

30 Sfântul Vasile cel Mare, Scrisori, Epistola 199 către Amfilohiu despre canoane..., p. 403: „ori pedeapsa pentru cei care desfrânează s-a hotărât să fie de patru ani"; a se vedea şi I. B. Pitra, Juris, t. I, p. 589. 
soţului necredincios care are legături nepermise cu o persoană care nu s-a căsătorit. Acest din urmă caz este cel pe care moraliştii moderni îl numesc adulter simplu. Pentru Sfântul Vasile cel Mare, acest păcat nu este clasificat în adulter, ci în desfrânare, care este o specie mult mai gravă. Şi într-adevăr, iată cazul propus de canonul 77:

„Cel care-şi lasă femeia cu care se unise în chip legiuit şi care-şi aduce apoi alta, se supune, după hotărârea Domnului, osândei adulterului. Părinţii noştri au lăsat nişte canoane, prin care au hotărît ca cei vinovaţ̧i să stea un an în rândul celor care se tânguiesc; doi ani între ascultători; şi trei ani între cei care se prostern. În al şaptelea an să stea în picioare, împreună cu credincioşii şi aşa să se învrednicească de aducerea jertfei liturgice dacă se vor pocăi cu lacrimi”’’31.

Prin urmare, numai şapte ani de penitenţă canonică sunt impuşi unui păcătos care este pedepsit mai puţin sever de către Sfinţii Părinţi decât de către Sfầnta Evanghelie. Care este acest păcat? Este adulterul comis de unul care se recăsătoreşte după ce a părăsit fără motiv, adică în afara cazului de adulter, pe soţia sa legitimă. Dacă ar fi vorba de bărbatul separat de femeie sa vinovată, textul nu ar spune: cel care-şi renunţă (katalimpanon), ci cel care trimite (apolysas, ca în Evanghelie, sau apopempsas, ca în canonul 21). Călugării de la Saint-Maur, care au editat operele Sfântului Vasile cel Mare ${ }^{32}$, găsesc, în favoarea acestui sens, un alt argument în termenii care desemnează pe femeie: „Cel care renunţă la femeia de care este legat în mod legitim" (ten nomimos auto synaphtheisav). Dacă ar fi vorba de o femeie adulteră, ea nu ar fi numită legitimă, spun ei, deoarece Sfantul Vasile cel Mare îl obligă pe soț să se despartă de ea, ceea ce înseamnă că el nu o mai consideră ca legitimă după păcatul ei. Vom vedea mai târziu, explicând canonul 9, că această afirmaţie este exagerată şi nefondată. Este clar, după cum au menţionat călugării de la Saint-Maur ${ }^{33}$, că soţul vinovat este obligat să-şi reia pe soţia lui

31 Sfântul Vasile cel Mare, Scrisori, Epistola 217 către Amfilohiu despre canoane..., p. 448; a se vedea şi I. B. Pitra, Juris, t. I, p. 599.

${ }^{32}$ Migne, P. G., 32, 803, n. 29.

${ }^{33}$ I. B. Pitra, Juris, t. I, p. 588. 
nevinovată şi să trimită pe complicele său înainte de a-şi începe pedeapsa. Şi ar trebui să fie recunoscător; el este tratat cu indulgență: el a comis un adulter adevărat şi nu este pedepsit ca şi desfrânaţii, pentru care canonul 59 fixează pedepsa la şapte ani. (Nu este loc să insistăm asupra unei mici divergenţe în detaliu între cele două canoane în distribuţia gradelor de penitenţă; cifra globală contează).

Canonul 21 prezintă un caz similar de pogorământ vis-a-vis de soţul vinovat:

„Dacă un bărbat vieţuind împreună cu o femeie nu se mulţumeşte de viaţa de căsătorie, ci cade în desfrâu, noi îl socotim desfrânat şi îi fixăm un timp mai îndelungat de pedepsire (decât unui simplu desfrânat); totuşi nu avem un canon care să ne dea drept să-l punem sub acuzarea de adulter dacă păcatul lui a fost săvârşit cu o femeie liberă de căsătorie, pentru că, zice Scriptura, femeia adulteră odată „,pângărită, pângărită va fi şi nu se mai întoarce la soţul ei” (Ieremia 3,1), iar ,,cel ce ţine pe cea adulteră este nebun şi necredincios" (Pilde 18, 23); dimpotrivă, cel ce a desfrânat cu ea nu va fi exclus de la împreunavieţuire cu soţia lui. De aceea, femeia îşi va primi soţul, dacă acesta se lasă de desfrâu, iar bărbatul va trimite la casa ei pe cea care s-a pângărit. Nu-i uşor să descoperi temeiul acestei practici, dar obiceiul aşa s-a încetăţenit" ${ }^{34}$.

Cazul semnalat aici nu este identic cu cel din canonul 77. Acolo, a fost vorba de bărbatul care îşi lasă soţia sa pentru nici un motiv, pentru a se recăsători, iar aici soţul care, fără a fi separat de soţia sa, trăieşte în desfrâu cu alta. Atât de o parte ca şi de alta, este adulter, după Evanghelie, şi se impune pedeapsa pentru desfrânaţi. $\mathrm{Cu}$ toate acestea, timpul de pedepsire este mai îndelungat decât cel pentru un desfrânat simplu. Dar nu numai despre pedeapsă soţul infidel se bucură de un tratament preferenţial, în virtutea în obiceiului sau a hotărârilor Părinţilor. Există, de asemenea un avantaj din punctul de vedere al separării. Hristos permite separarea (simplă) a soților în cazul de adulter (Matei 19, 9), dar nu o impune. Mai sever decât el, unele biserici vechi au făcut o obligaţie faţă de soţul

34 Sfântul Vasile cel Mare, Scrisori, Epistola 199 către Amfilohiu, despre canoane..., pp. 402-403. A se vedea şi I. B. Pitra, Juris, t. I, p. 588. 
nevinovat să divorţeze de soţia lui necredincioasă, în timp ce soţia nevinovată putea şi chiar trebuia să ţină soţul ei vinovat.

Exista, deci, o inegalitate evidentă, care nu era nici în epistolă şi nici în spiritul legii evanghelice, dar pe care circumstanţele au explicat-o. Este necesar să se recunoască aici, fără îndoială, influenţa legii civile. Ea a acordat soţului o situaţie atât de avantajoasă încât Părinţii, însărcinaţi să respecte legile evanghelice, au considerat prudent sau necesar să facă orice excepţie în favoarea sa, în unele cazuri determinate. Aşa se explică că pentru îndepărtarea femeii adultere de către soțul ei, îndepărtare permisă dar nu impusă de către Iisus Hristos, Biserica, temându-se să se ciocnească cu prejudecăţile atât ale celor convertiţi cât şi ale păgânilor obişnuiţi cu mai multă rigoare în legătură cu acest punct, a menţinut un obicei care, în sine, nu este în contradicţie cu cuvântul lui Hristos. Vom lăsa istoricilor grija de a adăuga la acest motiv al ordinei juridice şi alte cauze care apelează la acestă prudenţă. Ei vor găsi multe cauze, mai ales în situaţia foarte delicată pe care a creat-o în Biserică, în secolul al IVlea, intrarea în masă în sânul ei a păgânilor pe jumătate convertiţi, care, după ce au primit botezul, nu şi-au pierdut toate obiceiurile din trecut şi trebuiau să nu se descurajeze de cerinţele de mai sus ale forţelor lor. Doar treptat se putea lăsa să cadă pe aceşti umeri delicaţi toată greutatea crucii lui Hristos. Dacă femeia vinovată nu beneficia de aceleaşi îndulciri, fără îndoială ea a fost tot mai dispusă şi mai supusă, sau mai degrabă pentru că moravurile epocii înţelegeau mai bine gravitatea greşealei sale şi învoindu-se la aplicarea riguroasă a pedepsei stabilite.

$\mathrm{Cu}$ toate acestea, este important de menţionat că indulgenţa Bisericii din Cezareea, după canoanele citate mai sus, nu acoperă decât partea exterioară a disciplinei, penitenţa sau separarea. Nimic nu dovedeşte că Sfântul Vasile cel Mare a autorizat şi a recunoscut ca fiind valabilă căsătoria a doua a soţilor separaţi şi, prin urmare, că a admis ruptura completă a legăturii căsătoriei din vina unuia dintre soţi. Indulgenţa este toată rânduiala canonică şi penitenţială.

După aceste principii ar trebui să fie interpretat şi canonul 9. El nu conţine nimic mai mult şi vom încerca să arătăm acest lucru. 
Canonul 9. Iată textul integral. M-am gândit că ar trebui, pentru a orienta cititorul, să adăugăm împărţirea în paragrafe şi câteva cuvinte între paranteze, ale căror motive sunt, sau evident, vor fi prezentate în timp util.

„Hotărârea Domnului că nu-i îngăduit nimănui să se despartă, afară doar în caz de desfrânare, se potriveşte deopotrivă atât bărbaţilor cât şi femeilor, dacă urmărim desfăşurarea logică a ideii (kata ten akolouthian tes ennoias).

Dar obiceiul nu este aşa; căci în privinţa femeilor (adultere) aflăm rigurozitate multă în tratament; Apostolul, de pildă, ne spune că ,cel ce se lipeşte de o desfrânată este un singur trup cu ea" (I Corinteni 6, 16), iar Ieremia zice aşa: „Dacă o femeie se duce la alt bărbat, ea nu se va mai întoarce la bărbatul ei, ci pângărită fiind, rămâne pângărită" (Ieremia 3,1), şi iarăşi: ,cel ce ţine pe cea adulteră este nebun şi necredincios" (Pilde 18, 23).

Pe de altă parte, obiceiul rânduieşte ca, atât bărbaţii adulteri, cât şi cei ce trăiesc în desfrâu, să se reţină de la femei, de aceea nu ştiu dacă poate fi numită adulteră femeia care tăieşte cu un bărbat care a fost părăsit de soţia lui, deoarece aici vina cade asupra celei ce şi-a părăsit bărbatul, contează deci în primul rând pricina care a dus la desființarea căsătoriei. Căci dacă este bătută ori pentru că nu poate răbda bătăile, femeia trebuie să rabde mai vârtos decât să se despartă de soţ. Nu trebuie să se ţină seama nici de pierderea averilor, pe care ar invoca-o femeia. Chiar dacă soţul acela ar vieţui în desfrâu, nu avem în privinţa aceasta, în obiceiul bisericesc, această observaţie (paraterema). Şi nici n-a fost rânduit femeii să se despartă de un soţ necredincios, ci să rămână cu el din cauză că nu ştie care va fi sfârşitul. Căci ,ce ştii tu, femeie, dacă îţi vei mântui bărbatul?" (I Corinteni 7, 16). (a). De aceea, femeia care şi-a lăsat soţul şi s-a dus la altul este adulteră, pe când cel părăsit este iertat (dacă se recăsătoreşte) şi nici cea care trăieşte cu unul ca acesta nu se osândeşte.

În schimb, dacă bărbatul este cel care, după ce şi-a părăsit soţia, s-a dus la alta, este el însuşi adulter, pentru că o face şi pe dânsa adulteră, dar şi cea care vieţuieşte cu el e adulteră, pentru că a atras la ea un bărbat străin"35.

a) „Femeia nu a primit ordin de a se separa de soţul său necredincios, ci de a rămâne cu el, din cauza incertitudinii rezultatului. Căci, ştii tu, femeie, dacă îţi vei mântui bărbatul?" Sfârş̧itul propoziţiei, astfel tradus n-are sens. El spune 
În primul rând, este necesară o analiză a acestui canon.

Se observă mai întâi un fel de introducere pe care aş numi-o teologică unde se pune în principiu, după Evanghelie, egalitatea condiţiei soţilor din punct de vedere al separării. După acest preambul începe canonul propriu-zis, expus disciplinar. Acesta cuprinde trei părţi:

1. Interzicerea pentru soț de a trăi cu soţia lui adulteră, dar obligaţia de a o îndepărta, după Sfânta Scriptură;

2. Obligaţia pentru femeie de a-şi păstra pe soţul ei adulter, chiar dacă acesta este brutal, risipitor sau desfrânat; nimic, în Sfânta Scriptură sau în practica Bisericii, nu autorizează această plecare, astfel încât femeia nevinovată, care va pleca şi se va recăsători va fi pedepsită ca adulteră, în timp ce soţul vinovat şi abandonat care se va recăsători nu va fi tratat ca adulter pentru ea;

3. Interzicerea soţului de a se recăsători, sub pedeapsa comiterii adulterului, dacă el se desparte de soţia sa.

Unii autori, Palmieri ${ }^{36}$, Souran ${ }^{37}$, printre alţii, înţeleg ultima propoziţie despre fiecare soţ, care se separă de soţia sa, nevinovată sau adulteră. Ei au găsit aici un argument uşor în favoarea menţinerii absolute a legăturii conjugale şi răspunsul la dificultăţile pe care propoziţiile anterioare le-au ridicat. Această explicaţie pare adevărată. Cu toate acestea, ea dă loc la unele obiecţii serioase pe

contrariul faţă ceea ce a dorit să dovedească Sfântul Vasile cel Mare, sau el dă textului Epistolei către Corinteni un sens opus faţă de ceea ce dă Sfântul Apostol Pavel. Fără a recurge la un expedient prea convenabil a unei erori a copistului sau a unui rând uitat, putem să-i găsim un sens acceptabil, punând o separare după cuvântul paramenein, aşa cum face Pitra, şi repetând, înainte de partea a doua a propoziţiei, verbul primei propoziţii: alla chorizesthai proseiachthe dia to adelon... Acesta este sensul pe care l-am adoptat în traducerea mea. Mai mult decât atât, această propoziţie nu are decât un rol accesoriu în întregul canon.

35 Sfântul Vasile cel Mare, Scrisori, Epistola 188 către Amfilohiu, despre canoane, în Părinţi şi Scriitori Bisericeşti, vol. 12, pp. 379-380. A se vedea şi I. B. Pitra, Juris, t. I, p. 582.

${ }^{36}$ Palmieri, De Matrim. Christ., Rome, 1897, p. 169.

${ }^{37}$ Souran, „Adultère”, în Dictionnaire de théologique chatolique. 
care le ridică o parte din valoarea sa. Într-adevăr, atunci când este vorba despre o femeie adulteră, Sfântul Vasile cel Mare cere soţului, la începutul canonului, de a se despărţi de ea; cum se poate să-i reproşeze, la sfầrşitul aceluiaşi canon, acuzându-o „,că se face adulteră”, adică se expune păcatului (dioti poiei auten moicheuthenai). Auten desemnează cu siguranţă pe soţia legitimă, pentru că acest cuvânt este opusul lui he syvoikousa auto care desemnează pe complicele ei. Mai mult decât atât, aceste cuvinte sunt împrumutate de la Sfântul Evanghelist Matei $(5,32)$, unde se referă cu siguranţă la abandonarea femeii nevinovate, deoarece sensul propoziţiei este restrâns legat prin parektos logou porneias. Deşi se zice, în tot canonul 9, că este problema adulterului; dar se răspunde: este problema de adulter, sau al soţului sau al femeii, dar nu pretutindeni despre adulterul femeii. Toată partea a doua, de exemplu, este dedicată în principal pentru a se expune ceea ce trebuie să facă femeia nevinovată în caz de adulter al soţului ei. Acelaşi lucru poate fi şi în partea a treia. Aceste motive nu elimină toată probabilitarea interpretării care vede, în ultima propoziţie, condamnarea noii căsătorii a soţului. Ea pare numai acceptabilă, dar trebuie dovedită. Textul nu este de ajuns. $\mathrm{Cu}$ atât mai mult, nu este suficient să se rezolve numeroasele probleme pe care le ridică canonul.

Prima noastră grijă trebuie să fie pentru determinarea naturii obiceiului, synetheia, în numele căruia vorbeşte Sfântul Vasile cel Mare. Mulţi dintre autori au crezut că el a urmat aici legea civilă. Călugării de la Saint-Maur ${ }^{38}$ au afirmat acest lucru; Pitra ${ }^{39}$ 1-a acceptat, de asemenea, şi alţii după el. A priori, cest lucru nu este imposibil. Dar este evident că o astfel de declaraţie trebuie să fie demonstrată şi nu poate fi acceptată atât de uşor. Epistolele canonice nu sunt un comentariu civil al legilor imperiale, ci o expunere de reguli bisericeşti. Şi dacă se pretinde brusc că ele părăsesc terenul care este al lor pentru a face o incursiune în teritoriul vecin, trebuie stabilit cu fermitate aceste moduri de a vedea lucrurile. Ortodocşii,

\footnotetext{
${ }^{38}$ Migne, P. G., 32, 674, n. 64.

${ }^{39}$ I. B. Pitra, Juris, t. I, p. 614, n. 11.
} 
care confundă uşor legea civilă şi legea religioasă, sunt înclinaţi să acorde Părinţilor din secolul al IV-lea obiceiurile care sunt dintr-o altă epocă. Unii catolici au recunoscut, în cazul prezent, că Sfântul Vasile cel Mare a abandonat punctul de vedere bisericesc, pentru că anumite cuvinte ale canonului le-ar părea că sună rău. Dar, şi de o parte şi de alta, aceste motive sunt insuficiente.

Nu cred că se poate dovedi că Sfântul Vasile cel Mare a urmat, aici, legea civilă. Totul arată, dimpotrivă, că este vorba despre un obicei al Bisericii, sau, cel puţin, al unei Bisericii particulare. Susţinem acest punct de vedere din mai multe motive: 1) $\mathrm{Nu}$ există, în canon, nici cea mai mică menţiune despre legea civilă nici a unei autorităţi civile. Dimpotrivă, obiceiul este numit formal „bisericesc” (în mijlocul canonului). 2) Motivele prin care acesta este justificat nu sunt scoase din legi sau din constituţiile imperiale, ci din Sfânta Scriptură, Vechiul şi Noul Testament, sau din Sfinţii Părinţi. 3) Conţinutul, în ciuda unui număr de puncte de contact, conţine diferenţe semnificative, în special în ceea ce priveşte pe femeie, care nu este niciodată autorizată să se despartă, după Sfântul Vasile cel Mare, pe când legea civilă, Constituţia din 331, de exemplu, îi recunoaşte acest drept în mod oficial. 4) În aceeaşi scrisoare, canonul 4 stabileşte pedeapsa pentru cei ce se căsătoresc a treia oară după un obicei care este, cu siguranţă, bisericesc, autoritatea civilă nelegiferând niciodată pe această temă. $\mathrm{Nu}$ se poate admite că Sfântul Vasile cel Mare a desemnat rând pe rând prin acelaşi cuvânt, fără nici un avertisment, când un obicei civil, când un obicei bisericesc. La fel este desemnat pretutindeni. Eu nu pretind, de altfel, că nu există un rapoart de asemănare între cele două. Am spus doar că Sfầntul Vasile cel Mare nu se referă direct la autoritatea unei legi civile, ci la aceea a unui obicei bisericesc, care a putut să sufere şi a suferit influenţa celeilalte, am văzut numaidecât în ce fel şi în ce măsură.

La ce se referă acest obicei? Niciun dubiu cu privire la acest punct: el determină regulile de urmat în ceea ce priveşte separarea soţilor în caz de infidelitate al unuia dintre ei: obligaţia pentru soţul nevinovat să divorţeze de soţia lui adulteră; interzicerea femeii nevinovate de a îndepărta pe soţulul ei adulter. Aceasta este exact 
doctrina pe care am văzut-o expusă în canonul 21. Cu toate acestea, termenii care sunt utilizaţi aici de către Sfântul Vasile cel Mare reprezintă o problemă foarte gravă, aceea a indisolubilităţii legăturii conjugale. Ei par să presupună faptul că separarea în cauză este totală, completă şi permite o nouă căsătorie a unuia dintre soţi. Cele două propoziţii trebuie studiate fiecare în parte.

După interzicerea femeii de a se despărţi de soţul ei, chiar vinovat, el adaugă: ,aşa că, dacă soţul este părăsit, $n u$ ştiu dacă poate fi numită adulteră, femeia care locuieşte împreună cu el”; iar mai jos: „astfel că femeia care şi-a lăsat soţul este adulteră dacă se căsătoreşte; dar cel care a fost părăsit este de iertat (syggnostos) iar femeia care vieţuieşte cu el nu se osândeşte (ou katakrivetai)".

Tocmai doresc să subliniez, fără a insista, că cele două propoziţii nu sunt puse direct în raport cu obiceiul, dar că ele sunt separate prin cuvântul hoste, care anunţă o deducţie, un fel de concluzie personală. Se va remarca, de asemenea, că, spre deosebire de cele de mai sus, afirmaţia este aici ezitantă. Prima propoziţie este precedată de un ,eu nu ştiu”, care cade, de asemenea, asupra celei de a doua şi le ia o oarecare parte din greutatea lor. Dar să uităm pentru moment aceste detalii, şi să reţinem doar propoziţia a doua, care este formală şi explicită. Ce spune ea mai exact?

La prima vedere, se pare că are un singur sens, aceasta: „Soţul părăsit este liber să se recăsătorească şi noua sa soţie nu este adulteră, ci legitimă”.

$\mathrm{Cu}$ toate acestea, în cazul în care dorim să privim mai atent lucrurile, vom vedea că este posibil un al doilea sens: acest soţ nu poate fi pedepsit ca adulter; femeia nici nu poate fi adulteră (pentru că nu există canoane care să se refere la acest caz).

Şi nu numai acest al doilea sens este posibil, dar este adevărat, singurul pe care-1 putem trage cu certitudine din textul Sfântului Vasile cel Mare, singurul acceptabil în cazul de faţă. Iată o serie de motive care-1 insinuează sau care-1 dovedesc:

1. Termenii, luaţi în asprimea lor, nu spun ceea ce extrage prima traducere; dimpotrivă ei insinuează destul de puternic a doua. Scuzabil, termenul syggnostos, înseamnă demn de indulgenţă şi se foloseşte nu unei lucrări bune, nici chiar unei lucrări în întregime 
libere şi indiferente, ci unei acţiuni rele în sine şi de apărat; spunem că o greşeală este scuzabilă, o infracţiune este scuzabilă; dar ceea ce este permis nu are nevoie de o scuză. În plus, Sfầntul Vasile cel Mare a marcat bine gândirea sa atunci când, căutând un sinonim pentru scuzabil, nu spune despre femeie: ea este liberă; îi este permis, ci: nu se osândeşte. Prin urmare, termenii, luaţi în înţelesul lor, presupun mai degrabă interzicerea căsătoriei a doua decât libertatea.

2. Obiectul propriu, primul şi imediat al epistolelor canonice, este de a determina pedepsele pentru unele păcatele şi cazurile concrete în care acestea se aplică. Acestea nu sunt nici probleme de conştiinţă sau moralitate, nici răspunsuri teologice. Ele nu se ocupă de toate greşelile, nici chiar de cele mai grave în sine, ci de unele pedepse speciale judecate cu dreptate. Prin urmare, nu se poate baza nimic pe tăcerea lor. În ceea ce privește ceea ce ele exprimă, trebuie interpretat mai întâi într-un sens penal, iar aceasta nu poate ieşi decât dacă autorul arată, cel puţin indirect, intenţia sa de a generaliza problema.

3. Partea canonului care ne interesează este cu precădere canonică şi în special fraza pe care o studiem: femeia este declarată adulteră dacă se recăsătoreşte; soţul nu este în acelaşi caz. Este inacceptabil faptul că Sfântul Vasile cel Mare vorbeşte aici din punct de vedere moral sau teologic, din moment ce a declarat că, după Evanghelie, soţii sunt egali; diferenţa nu poate exista decât din punct de vedere canonic, adică penal; din cauza pedepsei el scuză căsătoria a doua. În plus, cum poate femeia care se retrage să fie adulteră recăsătorindu-se fără ca reciproca să fie adevarată? Adulterul presupune legături şi încă legături reciproce. Dacă femeia este legată şi soţul ei este legat. Cum poate fi scuzată să se recăsătorească? Scuza nu este despre a doua căsătorie însăşi, ci despre pedeapsa pe care o merită.

4. Canonul 46 prevede, în favoarea celui de al doilea sens, un argument care pare decisiv. El este foarte bine structurat:

„Femeia, care s-a căsătorit, fără să ştie, cu un bărbat părăsit pentru o vreme de soţia sa şi care apoi a fost alungată pentru că între timp cea 
dintâi s-a întors la dânsul, este o desfrânată, dar din neştiinţă. De aceea nu va fi oprită de la nuntă; însă mai bine ar fi dacă ar rămâne aşa" ${ }^{40}$.

Aici avem exact cazul care ne interesează: un soţ abandonat de către soţia lui. Cea care apoi s-a unit cu el este declarată vinovată de adulter, deşi ea este scuzată, din neştiinţă, de orice greaşeală categorică. Prin urmare, şi complicele său în mod egal şi fără nicio scuză, în afară de scuza sentinţei de adulter, conform obiceiului. Se poate, într-adevăr, să se obiecteze că soţul este abandonat ad tempus, iar cazul este diferit; dar acest fapt nu schimbă substanţa problemei. Intoarcerea femeii arată că plecarea sa a fost trecătoare, dar nu această întoarcere a făcut neregulamentară situaţia noii căsătorii. Păcatul a existat deoarece a persistat legătura. Prin urmare, soţul nu a fost dezlegat prin plecarea soţiei sale.

5. A admite o contradicţie formală la Sfântul Vasile cel Mare înseamnă a accepta primul sens. Sfântul Vasile cel Mare nu a fost lipsit de eroare; s-ar fi putut înşela asupra un anumit punct, după cum acest lucru s-a întâmplat şi la alţi Sfinţi Părinţi. Dar este mult mai dificil să acceptăm că el s-ar fi contrazis în mod expres asupra unui punct de o importanţă ca aceasta, şi nu trebuie să se rezolve decât înaintea evidenţei, pe baza textelor de o claritate deosebită astfel încât îndoiala să fie imposibilă. Am văzut mai sus gândirea lui precisă şi clară despre a doua căsătorie în caz de separare. Acest lucru ne obligă să alegem aici, între cele două sensuri acceptabile, pe acela care este în concordanţă cu această gândire, adică sensul al doilea.

6. În cele din urmă, această interpretare este confirmată prin comparaţie cu ceea ce s-a întâmplat în Apus, în aceeaşi perioadă, cu privire la subiectul unui caz cu o pedeapsă diferită pe care-1 vom discuta în acest moment. Să vedem Sinodul de la Elvira, în jurul anului 300, care, în canon $9^{41}$, interzice strict femeii să se

40 Sfântul Vasile cel Mare, Scrisori, Epistola 199 către Amfilohiu, despre canoane, în Părinţi şi Scriitori Bisericeşti, vol. 12, p. 408. A se vedea şi I. B. Pitra, Juris, t. I, p. 594; Dr. Nicodim Milaş, Canoanele Bisericii Ortodoxe, vol. II, part. II, p. 104.

${ }^{41}$ Hefele-Leclercq, Hisoire des conciles, t. I, p. 227. 
recăsătorească sub pedeapsa excomunicării. În schimb, câţiva ani mai târziu, în 314, Sinodul de Arles este chemat să se pronunţe cu privire la conduita credincioşilor tineri care, în timpul cât treiesc soţiile lor adultere de care sunt separaţi, închie a doua căsătorie, nu îndrăznește să-i lovească cu excomunicarea; el declară această căsătorie ilegală, dar, fără să stabilească o pedeapsă, sinodul cere doar că, ,pe cât posibil, sunt sfătuiţi să se abţină"42.

Şi iată-ne, cum la fel de natural, rămânem la „eu nu ştiu” (ouk oida) prin care Sfântul Vasile cel Mare abordează, în textul nostru, problema căsătoriei a doua. Aceasta înseamnă, fără îndoială: eu nu am cunoscut canoanele care se aplică în acest caz. Dar aceasta aminteşte şi mai mult, prin nehotărârea care-l trădează, de condescendenţa compătimitoare a Părinţilor Sinodul de la Arles.

Pentru toate aceste motive, concluzionăm că, fără aprobarea căsătoriei a doua a soţului părăsit, Sfântul Vasile cel Mare se arată indulgent cu el şi, în virtutea unui obicei stabilit în Biserica lui, suspendă aplicarea canoanelor de penitenţă care interzic adulterul. Să spunem că el îl scuteşte de orice sancţiune canonică şi îl primeşte în comuniunea Bisericii încă de când a îndepărtat pe complicele lui? Oricare ar fi posibilitatea unei astfel de concesiune, nu este nicio dovadă ca ea să fii existat. Nu se poate sprijini pentru a stabilit aceasta pe canonul 35, care nu se aplică în acest caz. El precizează: „În cazul bărbatului pe care 1-a părăsit soţia trebuie să se cerceteze care a fost cauza părăsirii şi dacă se constată că femeia a plecat fără motiv, bărbatul este vrednic de iertare; iar femeia trebuie pedepsită. Bărbatului i s-a dat această iertare pentru ca să păstreze mai departe comuniunea cu Biserica" ${ }^{43}$. $\mathrm{Nu}$ poate fi vorba aici de separare, urmată de o nouă căsătorie: canonul 46 , citat mai sus, care acuză femeia de desfrânare în acest caz, se opune în mod absolut. Mai mult decât atât, soţul părăsit, care încheie o nouă căsătorie, cel puţin ar fi

\footnotetext{
${ }^{42}$ Canonul 10 al Sinodului de la Arles, din 314, la Hefele-Leclercq, Histoire des conciles,t. I, p. 287.

43 Sfântul Vasile cel Mare, Scrisori, Epistola 199 către Amfilohiu, despre canoane..., p. 406. A se vedea şi I. B. Pitra, Juris, t. I, p. 592; Dr. Nicodim Milaş, Canoanele Bisericii Ortodoxe, vol. II, part. II, pp. 95-96.
} 
supus la pedeapsa pentru bigamie. Din moment ce este primit imediat la comuniunea Bisericii, nu este vorba aici decât de simpla separare a soţilor. Prin urmare, nimic nu se opune faptului ca, în cazul canonului 9 , soţul părăsit şi iertat pentru adulter, să fie totuşi supus unei înderdicţii a pedepselor pronunţate desfrânatului.

Trebuie să comparăm acest caz pe care îl vom studia cu cel al soţului nevinovat părăsit de soţia sa vinovată şi să conchidem că şi el a fost scutit de pedeapsa canonică a adulterilor în cazul în care se recăsătorea. Dacă soţul vinovat, părăsit de soţia sa, era scutit de pedeapsă, nu se putea arăta mai sever pentru un nevinovat separat de soția sa. Obligaţia care a fost făcută pentru acesta din urmă de a-şi lăsa soţia a militat încă în favoarea sa. Aşa cum se întâmplă de multe ori, această severitate excesivă asupra unui punct de disciplină trebuia să-şi găsească compensare în îmblânzirea celuilalt. Condamnând pe soţul nevinovat de a se despărţi de soţia sa, se punea aproape obligaţia morală de a-i impune o penitenţă mai mică în cazul în care el ceda tentaţiei de a lua pe alta, mai ales dacă era tânără.

Putem să mergem mai departe şi să spunem că Sfântul Vasile cel Mare permite soţului divorţat pe motiv de adulter să încheie o nouă căsătorie legitimă? Nimic nu dovedeşte acest lucru. Cei care au pretins aceasta, canoniştii ortodocşi medievali şi, printre catolici, editorii lucrărilor Sfầntului Vasile cel Mare, urmaţi de unii scriitori moderni, n-au adus în favoarea afirmaţiilor lor decât prezumţii vagi atunci când avem dreptul să aşteptăm, pentru o declaraţie de o asemenea importanţă, dovezi stabilite ferm. Ce spunem despre aceasta?

1. Despre faptul că dreptul roman considera căsătoria ca nulă prin adulterul femeii iar Sfântul Vasile cel Mare o urmează în acest cazul impunând separarea de soţul nevinovat, se ajune la concluzia că el gândeşte la fel. Dar neg faptul că Sfântul Vasile cel Mare urmează dreptul civil; el urmează obiceiul, ceea ce este diferit, chiar dacă acesta este influenţat de lege. Textele care sunt alese sunt împrumutate nu de la juriş̧i, ci din Sfầnta Scriptură.

2. Aceste texte biblice în sine nu dovedesc că Sfântul Vasile cel Mare consideră prima căsătorie nulă, ci numai că este o datorie a soţului nevinovat să divorţeze de soţia lui vinovată. (Nu voi discuta 
aici puterea demonstrativă a textelor citate; este cel puţin îndoielnică. Le-am luat ca pe nişte simple mărturii ale gândirii Sfântului Vasile cel Mare).

3. Dar de ce impune această obligaţie, dacă, pentru el, nunta este nulă? El o acceptă, spune el, pentru că acesta este obiceiul. Fie. Dar de ce acceptă acest obicei, dacă, pentru el, nu există o legătură adevărată între cei doi foşti soț?

Pentru că această concluzie a fost legitimă, trebuia ca anularea să fie singurul motiv pentru care putea să se încline Sfântul Vasile cel Mare să accepte obligaţia de a lăsa pe femeia adulteră. Dar acest lucru este fals. Mai sunt şi altele la fel de puternice. Voi expune unele; ele nu sunt singurele; se pot găsi şi altele. Atâta timp cât nu s-a stabilit că toate acestea sunt inadecvate şi că numai dizolvarea completă a primei căsătorii a fost în măsură să justifice decizia Sfântului Vasile cel Mare, nu s-a dovedit nimic.

4. În cele din urmă, să comparăm cazul de faţă, cu cel care a fost studiat anterior a soţului părăsit de soţia lui. Acolo, se spune, Sfântul Vasile cel Mare autorizează a doua căsătorie; cu atât mai mult trebuie să-l admitem aici. Am stabilit mai sus ceea ce trebuie să gândească. Neg că îl autorizează, cel puţin acest lucru nu se poate dovedi; nu 1-a pedepsit ca adulter, ceea ce este diferit. La fel este şi pentru soţul care a lăsat pe soţia sa adulteră; nu s-a dovedit nimic mai mult.

Astfel, un fapt rămâne incontestabil şi sigur, nu putem spune că Sfântul Vasile cel Mare, în scrisorile sale canonice, permite soţului divorţat să încheie a doua căsătorie, legală şi legitimă înaintea Bisericii, atâta timp cât trăieşte soţia sa. Ele pur şi simplu se abţin de a-1 pedepsi după cum merită în unele cazuri, ceea ce nu este o aprobare implicită, ci este o simplă toleranţă.

Acordă el femeii ceea ce refuză soţului? Aceasta este ultima întrebare care rămâne să fie studiată.

S-ar putea răspunde $a$ priori că femeia, a cărei infidelitatea este tratată de către Sfântul Vasile cel Mare cu toată rigoarea sa, nu va fi în mod evident mai favorizată decât soţul ei, care a beneficiat, uneori, de o mare indulgenţă şi, dacă a doua căsătorie este refuzată soţului divorţat de soţia lui care este în viaţă, cu atât mai mult va fi 
refuzată femeii divorţate de soţul ei care trăieşte. Merită, totuşi, truda pentru a intra în detaliile deciziilor luate cu privire la acest subiect.

Să presupunem mai întâi femeia nevinovată. Problema căsătoriei a doua se pune pentru ea în două cazuri: 1) ea este separată de soţul ei, pentru că el a întreţinut relaţii vinovate, sau pentru un alt motiv serios şi ea l-a părăsit; ea nu se poate recăsători fără a comite adulter (canonul 9), cu atât mai mult ar fi la fel dacă s-ar fi retras fără motiv; 2) ea este separată de soţul ei pentru că acesta a părăsit-o: ea nu se mai poate recăsători. Cazul este pus şi rezolvat prin canonul 48 care precizează următoarele:

„Femeia părăsită de bărbatul ei, după părerea mea, trebuie să rămână aşa (nemăritată), pentru că Domnul a spus: „oricine va lăsa pe femeia sa, afară de cuvânt de desfrânare, o face să săvârşească adulter" (Matei 5,32 ). Apoi, prin numirea ei de adulteră, a exclus-o pe dânsa de la împreunarea cu un alt bărbat. Cum poate fi acuzat ca pricină de adulter un astfel de bărbat, iar femeia care s-a numit de Domnul adulteră să fie nevinovată?" 44

Iată o exegeză foarte fină şi impecabilă. Dar de ce acest canon a interzis să se recăsătorească? Palmieri crede că este vorba de o femeie adulteră lăsată. Nu cred că se poate dovedi acest lucru. Toate indiciile arată mai degrabă contrariul: 1) alegerea textului evanghelic; dacă Sfântul Vasile cel Mare ar fi avut în vedere femea destituită, el ar fi trebuit să învoce următorul pasaj, qui dimissam duxerit, care nu este limitat cum este cel pe care-l citează prin excepta fornicationis causa; 2) întregul argument se referă la vinovăţia soţului care nu există în destituirea adulterului; 3) în cele din urmă, canonul 9, în secţiunea care se ocupă cu femeia adulteră, vorbeşte pe un alt ton decât acesta; acolo, Sfântul Vasile cel Mare găseşte în Sfânta Scriptură rânduieli precise şi bine definite; aici, el nu deduce învăţătura decât printr-un argument şi îl propune ca fiind opinia sa.

44 Sfântul Vasile cel Mare, Scrisori, Epistola 199 către Amfilohiu, despre canoane..., p. 409. A se vedea şi I. B. Pitra, Juris, t. I, p. 594; Dr. Nicodim Milaş, Canoanele Bisericii Ortodoxe, vol. II, part. II, p. 106. 
Prin urmare, nu este dovedit nici probabil că canonul 48 reglementează conduita adulterului şi o argumentare care ar presupune acest sens ar duce lipsă de soliditate. Noi nu putem afirma cu certitudine că interzicerea femeii nevinovate şi abandonate de către soțul o face să încheie o nouă căsătorie.

Rămâne cazul femeii adultere. Ea poate fi părăsită, după Evanghelie; ea trebuie să fie, după obiceiul pe care Sfântul Vasile cel Mare îl urmează. Poate ea, odată separată, să încheie o nouă căsătorie legitimă şi recunoscută ca atare de către Biserică? A pune întrebarea în aceşti termeni (iar aceasta în felul acesta se pune) înseamnă a o şi rezolva. $\mathrm{Nu}$ ne putem îndoi nicio clipă că el nu refuză femeii vinovate ceea ce refuză nevinovatei. Textele citate în canon 9 dovedesc destul de clar acest lucru: "Oricine se lipeşte de femeia adulteră este un singur trup cu ea”, adică adulter ca şi ea. Fără îndoială, această afirmaţie vizează în special pe soţ, de care Sfântul Vasile cel Mare este preocupat obligându-1 să se separe de soţia sa infidelă, dar este cu atât mai mult decât celelalte; dacă femeia este destrăbălată pentru sotul ei, cum n-ar fi pentru străini?

Se spune, într-adevăr, că autorul canonului consideră căsătoria desfăcută prin adulter. Dar am spus mai devreme că nu există nicio dovadă în acest sens. Şi în plus, din lipsă de alte motive, influenţa dreptului civil ar putea fi simţită aici, ca şi în alte probleme. Am văzut că adultera repudiată nu mai putea să încheie o căsătorie legitimă. Cum am putea accepta că o Biserică a fost mai îngăduitoare cu privire la această problemă? Prin urmare, este sigur că femeia adulteră destituită nu a putut să încheie o nouă căsătorie, fără a comite un nou adulter.

\section{Concluzii}

Cercetarea noastră despre divorţ la Sfântul Vasile cel Mare este completă. Fără îndoială gândirea Sfântului rămâne, în multe privințe, foarte obscură pentru noi. Dar, din punctul de vedere special de care ne ocupăm, a şti dacă Sfầntul Vasile cel Mare a acceptat o separare aşa încât ea să dea dreptul soților de a încheia o nouă căsătorie legitimă, următoarele puncte rămân incontestabile: 
1. Doctrina episcopului din Cezareea Capadociei este foarte clară în Regulile morale: căsătoria este apărată oficial de ambii soţi separaţi.

2. Practica, după Epistolele canonice ale Sfântului Vasile cel Mare, este mai puţin fermă: în timp ce căsătoria femeii divorţate este pedepsită întotdeauna ca adulteră, soţul nu este, în unele cazuri, dar nu există nicio dovadă că aceasta este autorizată şi recunoscută ca fiind validă.

Prin urmare, nu în canoanele penitenţiale trebuie să căutăm expresia deplină a gândirii Sfântului Vasile cel Mare, ci în propoziţia din Regulile morale: „Nu este îngăduit celui care şi-a lăsat femeia lui să se căsătorească cu alta, nici celei lăsate de bărbat să se căsătorească cu altul”45.

${ }^{45}$ Sfântul Vasile cel Mare, Regulile morale, 73, 2, în Părinţi şi Scriitori Bisericeşti, vol. 18, p. 187. 